\title{
TRANSNATIONAL CONTRACTS AND THEIR PERFORMANCE DURING THE COVID-19 CRISIS: REFLECTIONS FROM INDIA
}

\author{
SALONI KHANDERIA, \\ Jindal Global Law School (Sonipat, India)
}

https://doi.org/10.21684/2412-2343-2020-7-3-52-80

The outbreak of COVID-19 has severely impacted the performance of contracts across the globe. In some situations, the outbreak may render the performance of contracts impossible as a result of governmental restrictions in the form of national lockdowns to curb the spread of the virus. In other situations, the pandemic may adversely impact the execution of contractual obligations by dramatically affecting the price of the performance and, thus, resulting in hardship or commercial impracticability, while in certain situations the pandemic may be legally construed to not affect the performance of a contract. In domestic contracts, the consequences of such non-performance would depend on the principles of national law. In comparison, agreements with a foreign element (international contracts) are likely to increase the complexity of deciding claims arising from the non-performance of contracts due to the COVID-19 outbreak. The rights and liability of the parties would chiefly depend on the law that will govern the agreement - which differs across the globe. Some contracts would include a force majeure clause to exonerate the parties from performance on the occurrence of an event such as a pandemic. The courts' interpretations of such force majeure clauses similarly differ across the globe. The laws of some countries would excuse the parties from performing their contractual obligations even if the pandemic resulted in hardship. Others would strictly construe the terms of such clauses and would invalidate them if the occurrence of the pandemic did not make the performance impossible. This paper examines the non-performance of transnational contracts due to the COVID-19 outbreak when they are governed by Indian law. It highlights the situations when an international contract for the sale of goods or services whose performance has been allegedly hindered due to COVID19 would (a) frustrate and (b) breach the agreement under Indian law. The paper provides a comparative analysis of Indian law with jurisdictions such as France, Germany, Austria, China, the United Kingdom, Australia and the United States to demonstrate that Indian law is not well equipped to deal with complex lawsuits arising due to the non-performance of contracts as a result of the pandemic. 
Keywords: non-performance; international contract; Indian law; frustration of contract; force majeure clause; breach of contract; COVID-19.

Recommended citation: Saloni Khanderia, Transnational Contracts and Their Performance During the COVID-19 Crisis: Reflections from India, 7(3) BRICS Law Journal 52-80 (2020).

\section{Table of Contents}

\section{Introduction}

1. Global Responses to the Non-Performance of Contracts Due to the COVID-19 Pandemic

2. Non-Performance of International Contracts Governed by Indian Law

\subsection{Frustration of Contract}

2.2. Breach of Contract

\section{Predicaments in Applying Indian Law to Transnational Contracts Arising from Non-Performance as a Result of COVID-19 Conclusion}

\section{Introduction}

The doctrine of pacta sunt survanda refers to the sanctity of contracts and commits the parties to strict performance of their obligations under the agreement.' In certain circumstances, the strict performance may not be possible due to the occurrence of certain eventualities which impede the ability of the parties to perform the terms of the agreement according to their original contemplation.

The ongoing COVID-19 (coronavirus disease 2019) ${ }^{2}$ crisis which was declared a global emergency by the World Health Organization (WHO) on 11 March $2020^{3}$ succinctly illustrates this aspect. In some circumstances, the pandemic has acted as

\footnotetext{
See Art. 26 of the 1969 Vienna Convention on the Law of Treaties in relation to international law; Sapphire International Petroleums Ltd. v. National Iranian Oil Co., Arbitral Award, 15 March 1963, (1967) 35 I.L.R. 136, 181; Libyan American Oil Co. (LIAMCO) v. Libya, Arbitral Award, 12 April 1977, (1981) Y.C.A. 89, 101; and Andrew Kull, Mistake, Frustration, and the Windfall Principle of Contract Remedies, 43 Hastings Law Journal 1, 6 (1991).

2 See WHO, WHO Best Practices for Naming of New Human Infectious Diseases, WHO_HSE_FOS_15.1 (May 2015) (Jul. 2, 2020), available at https://www.who.int/topics/infectious_diseases/naming-newdiseases/en/.

3 SeeWHO Director-General's Opening Remarks at the Media Briefing on COVID-19, WHO, 11 March 2020 (Jul. 2, 2020), available at https://www.who.int/dg/speeches/detail/who-director-general-s-openingremarks-at-the-media-briefing-on-covid-19---11-march-2020.
} 
an impediment and has rendered the performance of contracts impossible. Contracts in the aviation, travel and tourism industries have faced an unprecedented crisis due to the sudden declaration of national lockdowns in most parts of the world. ${ }^{4}$ In other situations, the occurrence of the pandemic may have rendered the execution of contractual obligations more onerous by dramatically affecting the price of the performance. The World Bank reports that the outbreak has resulted in a "major shock to the already fragile global outlook" and has led to a sharp decline in commodity prices. ${ }^{5}$ For instance, the "collapse" of the travel industry due to national lockdowns to curb the outbreak has led to a dramatic decrease in the price of oil by 50 per cent. ${ }^{\circ}$ The travel disruptions from East Africa to Europe have also been reported to result in an 80 per cent drop in the export of fresh flowers from Kenya due to the disruption in the supply chain consequently affecting its price by pushing it higher. In a related vein, the implementation of enhanced border checks due to COVID-19 is predicted to permanently increase the cost of transportation which in turn will impact the prices of most products.' The United Nation's Food and Agriculture Organisation (FAO) has also reported a sharp increase in food prices and, in particular, those of meat, poultry, fish and egg items due to the pandemic. In some situations, however, the performance of the contractual obligation would not be construed to have been affected by the outbreak of COVID-19. This would typically be the position for contracts concluded after the declaration of COVID-19 as a pandemic by the WHO on 11 March 2020. In such circumstances, the parties may be liable for breach of contract.'

In the case of domestic agreements, the redress available to the parties for any form of non-performance of contractual obligations including that which has been prompted by the pandemic will depend on the provisions of the national law of

4 See, generally, Tourism Policy Responses to the Coronavirus (COVID-19), Organisation for Economic Co-operation and Development (OECD), 2 June 2020 (Jul. 2, 2020), available at https://www.oecd. org/coronavirus/policy-responses/tourism-policy-responses-to-the-coronavirus-covid-19-6466aa20/; and United Nations Conference on Trade and Development (UNCTAD), COVID-19 and Tourism: Assessing the Economic Consequences (July 2020) (Jul. 2, 2020), available at https://unctad.org/en/ PublicationsLibrary/ditcinf2020d3_en.pdf.

5 See The World Bank, A Shock Like No Other: The Impact of COVID-19 on Commodity Markets (April 2020), at 7 (Jul. 2, 2020), available at http://pubdocs.worldbank.org/en/558261587395154178/CMOApril-2020-Special-Focus-1.pdf.

6 Id.; and A Shock Like No Other: Coronavirus Rattles Commodity Markets, The World Bank, 23 April 2020 (Jul. 2, 2020), available at https://www.worldbank.org/en/news/feature/2020/04/23/coronavirusshakes-commodity-markets.

7 The World Bank, Impact of COVID-19, supra note 5, at 14.

8 See World Food Situation, FAO, 3 September 2020 (Jul. 2, 2020), available at http://www.fao.org/ worldfoodsituation/foodpricesindex/en/.

9 See, for instance, Extenuating Circumstances Policy and the Coronavirus (COVID-19), Airbnb, 1 August 2020 (Jul. 2, 2020), available at https://www.airbnb.co.in/help/article/2701/extenuating-circumstancespolicy-and-the-coronavirus-covid19. 
contract. In agreements with a foreign element - namely international contracts ${ }^{10}-$ the determination of the rights and liabilities of the parties will, however, chiefly depend on the law that governs the contract, which will be identified according to the rules of private international law of the adjudicating forum. " For instance, a contract concluded between an Indian party and a South African party for the sale of cotton bedspreads may expressly stipulate the application of French law which the parties prefer for its neutrality. In another situation, the adjudicating forum may identify the application of French law because of its connection with the transaction - such as when the products were supposed to be delivered in France.

For all that, the very diversity in the legal principles on the subject among countries across the globe is likely to increase the complexity in adjudicating such claims. Some contracts may contain a force majeure clause which expressly permits the parties to terminate the agreement if the performance has been deterred by eventualities such as an epidemic or a pandemic; others may not. The courts in some countries may validate the force majeure clauses - because it expresses the intention of the parties. In contrast, others may subject the interpretation of such clauses to stringent precepts. Conflicts such as these have resulted in the pandemic being referred to as a "recipe for litigation"12 considering that such disputes cannot be subjected to any straightjacket formula.

This paper examines the consequences of non-performance of an international contract due to the occurrence of the pandemic when it is governed by Indian law. Part one highlights the global response to the pandemic under the laws of several major jurisdictions, specifically France, Germany, Austria, Italy, Greece, China, the United States, the United Kingdom, Hong Kong, and Australia. Part two focuses on Indian law. In particular, it identifies the circumstances in which the contract will be considered to be (a) frustrated and (b) breached as a result of non-performance due to the COVID-19 outbreak. Part three identifies the gaps in Indian law. In the concluding remarks, the paper offers a critique on the Indian law of contract's suitability to govern domestic and transnational agreements.

10 The Hague Conference on Private International Law reports that the term "international" has not been uniformly defined, and its meaning differs across national and international instruments. According to the 2015 Hague Principles on the Choice of Law in International Commercial Contracts, a contract would be regarded as "international" "unless each party has its establishment in the same State and the relationship of the parties and all other relevant elements, regardless of the chosen law, are connected only with that State."

11 For a detailed discussion on this aspect, see Saloni Khanderia \& Sagi Peari, Party Autonomy and the Choice of Law Under Indian and Australian Private International Law: Some Reciprocal Lessons, Commonwealth Law Bulletin (Forthcoming 2020).

12 See Jos Hoevenaars \& Xandra Kramer, Mass Litigation in Times of Corona and Developments in the Netherlands, Conflict of Laws.net, 22 April 2020 (Jul. 2, 2020), available at https://conflictoflaws. net/2020/mass-litigation-in-times-of-corona-and-developments-in-the-netherlands/, referring to Jenna Greene, Daily Dicta: Big Law Litigators See COVID-19 as a 'Recipe for Litigation', Law.com, 17 March 2020 (Jul. 2, 2020), available at https://www.law.com/litigationdaily/2020/03/17/daily-dicta-big-lawlitigators-see-covid-19-as-a-recipe-for-litigation/?slreturn=20200901152607. 


\section{Global Responses to the Non-Performance of Contracts Due to the COVID-19 Pandemic}

In general, the term "non-performance" refers to "the failure by a party to perform any of its obligations under the contract.."13 It includes defective or late performance. ${ }^{14}$ The term, therefore, includes the inability to perform the contractual obligations for any reason.

As indicated earlier, the performance of some contracts has been severely impacted due to the outbreak of the COVID-19 pandemic and the imposition of governmental restrictions to curb the spread of the virus. In this respect, some governments have issued force majeure certificates to its traders to address the problems of non-performance of contracts due to the COVID-19 outbreak. The governments of Italy ${ }^{15}$ and Greece ${ }^{16}$ have stated that agreements in transport, accommodation and package travel contracts will be regarded as overriding mandatory norms of their respective laws. This means that such agreements will be considered to be impossible to perform regardless of the law chosen by the parties." There is no uniform criterion to identify the circumstances in which a provision in law will assume the character of an overriding mandatory norm. Nygh articulates that a provision will be considered to be mandatory if the law of the forum (lex fori) desires its application regardless of the choice of another legal system. ${ }^{18}$ Mandatory rules are a subspecies of public policy insofar as they perform certain special functions, such as a marriage law which prohibits polygamy. ${ }^{19}$ To illustrate, a contract is concluded

13 See Art. 7.1.1 of the UNIDROIT Principles of International Commercial Contracts (PICC). The PICC is available at https://www.unidroit.org/english/principles/contracts/principles2016/principles2016-e. pdf. For a detailed discussion on the UNIDROIT, see Jan Kropholler, Internationales Einheitsrecht: Allgemeine Lehren 57-59 (Tübingen: J.C.B. Mohr (Paul Siebeck), 1975) (translated from German original); Stefan Vogenauer, Introduction in Commentary on the UNIDROIT Principles of International Commercial Contracts (PICC) 7 (S. Vogenauer (ed.), $2^{\text {nd }}$ ed., Oxford: Oxford University Press, 2015); and the UNIDROIT website (Jul. 2, 2020), available at www.unidroit.org/about-unidroit/overview.

14 Id.

15 See Art. 28 of Decree-Law No. 9/2020 and Art. 88 of Decree-Law No. 18/2020 (dated 17 March 2020) read along with Art. 1463 of the Italian Civil Code. Also see Ennio Piovesani, Italian Self-Proclaimed Overriding Mandatory Provisions to Fight Coronavirus, Conflict of Laws.net, 19 March 2020 (Jul. 2, 2020), available at https://conflictoflaws.net/2020/italian-self-proclaimed-overriding-mandatoryprovisions-to-fight-coronavirus/.

16 See Arts. 61, 65, 70 and 71 of Acts of Legislative Content of 13 April 2020, read along with Art. 44 of the Greek Constitution. Also see Apostolos Anthimos, COVID-19 and Overriding Mandatory Provisions, Conflict of Laws.net, 15 April 2020 (Jul. 2, 2020), available at https://conflictoflaws.net/2020/covid19-and-overriding-mandatory-provisions/.

17 Id.

18 Peter E. Nygh, Autonomy in International Contracts 199 (Oxford: Clarendon Press; New York: Oxford University Press, 1999).

19 Id. at $199-207$. 
on 1 March 2020 between an American citizen and a hotel in Rome to provide accommodations to the former during his visit to Italy from 1 to 7 April 2020. The contract stipulates the application of the law of New York. Such an agreement will be regarded as impossible to perform under Italian law irrespective of whether New York law states otherwise.

In a related vein, the governments of Russia ${ }^{20}$ and $\mathrm{China}^{21}$ have issued force majeure certificates to absolve companies which are located in their territories from liability for non-performance of contractual obligations with foreign parties as a result of the outbreak of the pandemic.

In international contracts, in the absence of such force majeure certificates, the consequences of non-performance due to the COVID-19 outbreak will depend on the governing law which will be identified according to the rules of private international law of the forum. The application of the laws of civil law jurisdictions such as France, ${ }^{22}$ Austria, ${ }^{23}$ Germany, ${ }_{1}^{24}$ Greece, ${ }_{1}^{25}$ Italy, ${ }_{1}^{26}$ the Netherlands, ${ }_{1}^{27}$ Scandinavian countries, ${ }_{1}^{28}$ and $\mathrm{China}^{29}$ stipulate a dichotomy in their approach towards providing redress for nonperformance due to the occurrence of sudden and unforeseen eventualities such as COVID-19. There are two principles to regulate the non-performance of contracts due to unforeseen, supervening impediments - these being the doctrines of force majeure $e^{30}$

20 See Ekaterina Pannebakker, 'Force Majeure Certificates' Issued by the Russian Chamber of Commerce and Industry, Conflict of Laws.net, 17 April 2020 (Jul. 2, 2020), available at https://conflictoflaws.net/2020/ force-majeure-certificates-by-the-russian-chamber-of-commerce-and-industry/.

21 Sophia Tang, Coronavirus, Force Majeure Certificate and Private International Law, Conflict of Laws.net, 1 March 2020 (Jul. 2, 2020), available at https://conflictoflaws.net/2020/coronavirus-force-majeurecertificate-and-private-international-law/.

22 See Unexpected Circumstances in European Contract Law 144-145 (E. Hondius \& H.C. Grigoleit (eds.), Cambridge: Cambridge University Press, 2011).

23 See Secs. 936, 1052, and 1170a of the Austrian Bügerliches Gesetzbuch (BGB), 1811.

24 See Sec. 313 of the German BGB, 1900.

25 See Art. 388 of the Greek Civil Code, 1946.

26 See Art. 1467 of the Italian Codice Civile, 1942.

27 See Art. 6:258 of the Dutch Civil Code, 1992.

28 See Art. 6.111 of the Principles of European Contract Law (The Hague: Kluwer International Law, 1999) [PECL 1999].

29 See Art. 117 of the Chinese Contract Law 1999; and Art. 26 of the Supreme People's Court of the People's Republic of China [SPC], Interpretation II of the Supreme People's Court on Several Issues concerning the Application of the Contract Law of the People's Republic of China, Fa Shi [2009] No. 5, 13 May 2009.

30 For a detailed discussion on force majeure in civil law jurisdictions, see Marel Katsivela, Contracts: Force Majeure Concept or Force Majeure Clauses?, 12(1) Uniform Law Review 101, 112 (2007). Also see, generally, Ingeborg Schwenzer, Force Majeure and Hardship in International Sales Contracts, 39(4) Victoria University of Wellington Law Review 709 (2009) [Schwenzer, Force Majeure and Hardship], for a detailed discussion on the difference between force majeure and hardship. 
and hardship. ${ }^{31}$ The redress available to the parties will necessarily depend on the impact of the pandemic on the performance of the contractual obligations. Force majeure refers to situations attributable to acts of God or vis major..$^{32}$ Hardship refers to a change in circumstance which has not rendered the performance impossible but has severely altered the equilibrium between the parties due to the occurrence of sudden legal, political or economic changes. ${ }^{33} \mathrm{Hardship}$ may increase the cost of performance or may result in a diminution in the value that the affected party would otherwise receive in the absence of such circumstances.

The doctrine of force majeure will exonerate the parties from liability for nonperformance if the occurrence of the pandemic is sudden and unforeseen and has rendered the execution impossible to execute. ${ }^{34}$ In such circumstances, the parties may terminate the contract. A contract will be construed as impossible to perform if its performance was impeded by an uncontrollable event, such as that led by the government. ${ }^{35}$ By this principle, a self-imposed lockdown will not be regarded as an impossible event and will not excuse the performance of the contract. ${ }^{36}$ In the case of hardship, the parties may renegotiate the terms of the agreement to accommodate the changed scenario. ${ }^{37}$ The termination of the contract would be permitted only if the parties were unable to find a just and viable solution to resolve the matter. ${ }^{38}$

31 For a detailed discussion on the doctrine of hardship, see Saloni Khanderia, Commercial Impracticability Under the Indian Law of Contract: Assessing the Role of the UNIDROIT Principles, 7(2) UCL Journal of Law and Jurisprudence 52, 54-62 et seq. (2019) [Khanderia, Commercial Impracticability].

32 See, for instance, Art. 1218 of the Italian Codice Civile; Art. 6.75 of the Dutch Civil Code; Arts. 275 and 326 of the German BGB, which by default restrict the applicability of its provisions on impossibility to acts of God. Accordingly, other events such as war and strike must be expressly included in the contractual terms. Cf. Art. 1148 of the French Civil Code; Art. 1470 of the Québec Civil Code; Art. 336 of the Greek Civil Code; Art. 8.108 of the PECL 1999; and Art. III-3:104 of the Principles, Definitions and Model Rules of European Private Law, Draft Common Frame of Reference, Prepared by the Study Group on a European Civil Code and the Research Group on EC Private Law (Munich: Sellier, 2008) [DCFR 2008], which by default extend the doctrine of force majeure to any impediment, including those that are internal to a contractual party's sphere of risk, such as war and strike.

33 See, for instance, Art. 6.111 of the PECL 1999; and Art. III-1:110(3)(d) of the DCFR 2008.

34 See Joseph M. Perillo, Force Majeure and Hardship Under the UNIDROIT Principles of International Commercial Contracts, 5 Tulane Journal of International and Comparative Law 5, 6 (1997); Sarah Howard Jenkins, Exemption for Nonperformance: UCC, CISG, UNIDROIT Principles - A Comparative Assessment, 72 Tulane Law Review 2015, 2020 (1998); and Khanderia, Commercial Impracticability, supra note 31, at 56.

35 Khanderia \& Peari, Party Autonomy: Reciprocal Lessons, supra note 11.

36 Id.

37 See, for instance, Unexpected Circumstances in European Contract Law, supra note 22, at 144-145 for a discussion on French law; Secs. 936, 1052, and 1170a of the Austrian Bügerliches Gesetzbuch (BGB), 1811; Sec. 313 of the German BGB, 1900; Art. 388 of the Greek Civil Code, 1946; Art. 1467 of the Italian Codice Civile, 1942; Art. 6:258 of the Dutch Civil Code, 1992; and Art. 6.2.2 of the PICC.

38 See, for instance, Art. 6.2.3 of the PICC; Art. 6.111(2) of the PECL 1999; and Art. III-1:110(3)(d) of the DCFR 2008. Also see Art. 6.5.3.11 of the Dutch Civil Code, which highlights the reluctance of Dutch courts in adapting the contract on account of hardship. Therefore, the Dutch courts will terminate the contract if the parties were unable to agree to renegotiate the terms of the contract. 
In common law jurisdictions such as the UK, Hong Kong and Australia, the consequences of non-performance due to an unforeseen, supervening event are regulated under the doctrine of "frustration of contract" ${ }^{\prime \prime 39}$ which is similar to the principle of force majeure. As Rapsomanikas articulates, "The situation expressed by all these words is basically the same." ${ }^{\prime \prime}$ However, unlike the civil law jurisdictions, the legal principles of common law countries do not stipulate a dichotomy in the redress offered for non-performance due to an unforeseen event such as COVID-19. The laws of these countries will not excuse the performance of the contract unless the occurrence of the pandemic was (a) unexpected and (b) rendered the performance impossible. ${ }^{41}$ The supervening impediment such as the outbreak of COVID-19 will render the performance impossible if the agreement has become fundamentally different from the original contemplation of the parties due to a supervening illegality, a cancellation of an event which formed the basis of the agreement or illness or death of one of the parties. The fact that the contract becomes more challenging to perform will not be sufficient to frustrate the contract under common law unless the parties can demonstrate at least a "hundredfold increase" in the price. ${ }^{42}$ Judicial dicta elucidate a "hundredfold increase" in the price as an unlikely and fantastic contingency. ${ }^{43}$

An examination of the dictum of the Hong Kong Court in Li Ching Wing v. Xuan Yi Xiong ${ }^{44}$ sheds light on the application of the doctrine of frustration to the nonperformance of contracts due to pandemics. In this case, the court refused to exonerate the tenant from performing a two-year lease of a property on being subjected to a ten-day quarantine order due to the outbreak of the Severe Acute Respiratory Syndrome (SARS) in 2003. ${ }^{45}$ The court stated that unforeseen events such as SARS would frustrate the contract by rendering it impossible if the outstanding contractual

39 For a detailed discussion on the doctrine of frustration under the English common law, see Michael G. Rapsomanikas, Frustration of Contract in International Trade Law and Comparative Law, 18 Duquesne Law Review 551 (1980); and Guenter Treitel, Frustration and Force Majeure 256 et seq. ( $3^{\text {rd }}$ ed., London: Sweet and Maxwell, 2014). Also see British Movietonews Ltd. v. London and District Cinemas [1952] A.C. 166, 185 per Lord Simon; and Wates Ltd. v. Greater London Council, [1984] 25 B.L.R. 1; Brauer \& Co. (Great Britain) Ltd. v. James Clark (Brush Materials) Ltd. [1952] 2 All E.R. 497, 501 per Lord Denning; Taylor v. Caldwell, 122 Eng. Rep. 309 (Q.B. 1863); and Krell v. Henry, [1903] 2 K.B. 740.

$40 \quad$ Id.

${ }^{41}$ See the decisions of the English courts in Taylor v. Caldwell, 122 Eng. Rep. 309 (Q.B. 1863); and Krell v. Henry, [1903] 2 K.B. 740.

42 See British Movietonews Ltd. v. London and District Cinemas [1952] A.C. 166, 185 per Lord Simon; and Wates Ltd. v. Greater London Council, [1984] 25 B.L.R. 1; Treitel 2014, at 299-300; and Khanderia, Commercial Impracticability, supra note 31, at 58.

43 See Khanderia, Commercial Impracticability, supra note 31, at 58, referring to Brauer \& Co (Great Britain) Ltd. v. James Clark (Brush Materials) Ltd., [1952] 2 Lloyd's Rep. 147 (C.A.) 501 per Lord Denning; and Treitel 2014, at 282, $38 \mathrm{ff}$.

44 [2004] 1 H.K.L.R.D. 754.

45 Id. 
rights or obligations are significantly changed ${ }^{46}$ The court's dictum demonstrates that the application of the doctrine of frustration to the non-performance of contracts due to the COVID-19 outbreak will depend on the terms of the agreement and the nature of restrictions imposed.

In a related vein, the United States too does not adopt a dichotomy in the solutions offered for non-performance due to unforeseen impediments such as the COVID-19 pandemic. At the same time, unlike the practice in other common law countries, U.S. law does recognise hardship - which it refers to as commercial impracticability. Section 2-615 of the Uniform Commercial Code 1978 [UCC], which applies in part to all fifty states, which is read along with section 261 of the Restatement Second [Restatement 2d] will excuse the parties from performing their obligations if an "extreme or unforeseen difficulty or expense" has altered the nature of the performance of the terms of the contract. ${ }^{47}$ An impediment in the form of dramatic price rise would constitute commercial impracticability only if it formed the "basic assumption on which the contract was concluded." ${ }^{48}$ Therefore, "a simple rise or fall in prices would not amount to impracticability unless it was'well beyond the normal range' or 'wholly abnormal."'49 That said, unlike the practice of civil law countries, U.S. law will not permit the parties to renegotiate the terms of their contract to accommodate sudden and dramatic price increases. However, the legal system will redress the parties when the contract becomes more onerous by permitting them to terminate the agreement - unlike the practice in countries following the English common law. In this manner, the United States equates impossibility with commercial impracticability.

In international commercial contracts ${ }^{50}$ on the sale of goods, ${ }^{51}$ the United Nations Convention on Contracts for the International Sale of Goods (CISG) $)^{52}$ may replace the provisions of national law if (a) the parties have their business in different states which are signatories to the instrument or (b) if the rules of private international law of the forum have led its application..$^{53}$ The provisions of the CISG exonerate the parties from liability for non-performance if it is attributable to an impediment

46 [2004] 1 H.K.L.R.D. 754.

47 See Comment 4 to Sec. 2-615 of the UCC; and Comment (d) to Sec. 261 of the Restatement 2d.

48 Id.; and Treitel 2014, at 256 et seq.; and Khanderia, Commercial Impracticability, supra note 31, at 57.

49 See Khanderia, Commercial Impracticability, supra note 31, at 57 referring to Treitel 2014, at 278, $34 \mathrm{ff}$.

50 See Art. 2 of the CISG, which defines the scope of the instrument.

51 Id. Art. 3, which clarifies the circumstances in which, an international commercial contract will be for the sale of goods.

52 For a list of signatories to the CISG, visit, http://www.uncitral.org/uncitral/en/uncitral_texts/sale_goods/ 1980CISG_status.html.

53 See Art. 1 of the CISG. 
beyond their control which they could not have reasonably taken into account at the time of the conclusion of the contract..$^{54}$ The CISG does not expressly indicate the acceptance of hardship. Academic writings are divided on this aspect. Some authors opine that the term "impediment" includes hardship and the CISG would, accordingly, excuse the parties from termination if the equilibrium of their contract has been fundamentally altered and has been made more onerous to perform. ${ }^{55}$ Others state that the CISG restricts the interpretation of the term "impediment" to a force majeure event. ${ }^{56}$

In all other circumstances, the parties will be liable for breach of contract (also known as "non-excused non-performance" $)^{\prime 57}$ if the inability to perform cannot be attributed to any extraneous circumstance under the applicable law. This will be the position in situations such as when the parties have been unable to execute the contractual obligations due to a self-imposed lockdown or when the sudden increase in the price of performance is not considered to be "dramatic" in a manner that fundamentally alters the equilibrium of the parties under the applicable law. ${ }^{58}$ In general, the laws of several countries such as the UK ${ }_{1}^{59}$ Ireland ${ }^{60}$ Denmark, ${ }_{10}^{61}$ Finland ${ }^{62}{ }_{\text {Italy }}{ }^{63}$ Sweden, ${ }^{64}$ the United States, Bolivia, ${ }^{65}$

54 Art. 79 of the CISG.

55 See Ingeborg Schwenzer in Commentary on the UN Convention on the International Sale of Goods (CISG) (P. Schlechtriem \& I. Schwenzer (eds.), $4^{\text {th }}$ ed., Oxford: Oxford University Press, 2016), Art. 79, para. 4 [Schwenzer, Commentary on the CISG]; Schwenzer, Force Majeure and Hardship, supra note 30, at 712713; Ole Lando \& Hugh Beale, Principles of European Contract Law - Full Texts of Parts I and II Combined 322-328 (The Hague: Kluwer Law International, 2000); Christopher Brunner, Force Majeure and Hardship under General Contract Principles: Exemption for Non-Performance in International Arbitration 167 (The Hague: Kluwer Law International, 2009); Daniel Girsberger \& Paulius Zapolskis, Fundamental Alteration of the Contractual Equilibrium under Hardship Exemption, 19(1) Jurisprudencija 121, 122 (2012); and Niklas Lindstroöm, Changed Circumstances and Hardship in the International Sale of Goods, 1 Nordic Journal of Commercial Law 23-24 (2006).

56 See Jenkins 1998, at 2025.

57 See UPICC, Art. 7.1.1 read along with the Official Comment, 227-228; and Art. of the CISG.

58 See the text accompanying notes $22-43$.

59 See the decision of the courts in Bunge Corp. v. Tradax S.A. [1981] 1 W.L.R. 711, H.L.; and Hong Kong Fir Shipping Co Ltd. v. Kawasaki Kisen Kaisha Ltd. [1962] 2 Q.B. 26, C.A.

60 See the decision of the court in Clayton Love v. B. \& I. Line (1970) 104 I.L.T.R. 157.

61 See Secs. 21, 28, 42 and 43 of the Sale of Goods Act of Denmark.

62 See Secs. 25, 39, 54 and 55 of the Sale of Goods Act of Finland.

63 See Art. 1455 of the Italian Codice Civile, 1942.

64 See Secs. 25, 39, 54 and 55 of the Sale of Goods Act of Sweden.

65 See Alberto L. Zuppi, A Comparison of Buyer's Remedies Under the CISG with the Latin American Legal Tradition, Review of the Convention on Contracts for the International Sale of Goods 3, 39 (1999) (Jul. 2, 2020), also available at http://www.cisg.law.pace.edu/cisg/biblio/zuppi.html; and Eduardo Grebler, Fundamental Breach of Contract under the CISG: A Controversial Rule, 101 American Society of International Law Proceedings 407, 410-411 (2007). 
Paraguay, ${ }_{1}^{66} \mathrm{Brazil}_{1}{ }^{67}$ and the $\mathrm{ClSG}^{68}$ will permit the parties to terminate the contract if the non-performance is regarded as "fundamental"-i.e. substantial or material. In comparison, the laws of legal systems such as Austria, ${ }_{1}^{69}$ Germany ${ }_{1}^{70}$ and Greece ${ }^{71}$ do not adopt a unitary concept of a breach which stipulates the circumstances in which non-performance will be regarded as "fundamental." However, the termination will not be permitted unless the party in default has violated a "main" as opposed to a "subordinate" obligation." Therefore, minor deviations from the contractual terms will not entitle the parties to terminate the contract. ${ }^{73}$ The parties will, however, be entitled to damages for such nonperformance. $^{74}$

\section{Non-Performance of International Contracts Governed by Indian Law}

According to the private international law of India, a contract is considered to be "international" if (a) one of the parties has a business located abroad; (b) the agreement was to be performed elsewhere; (c) the subject matter of the transaction is located overseas; or (d) when one of the parties to the transaction is a foreigner. ${ }^{75}$

All disputes arising from international contracts which are governed by Indian law are adjudicated according to the provisions of the Indian Contract Act 1872 (ICA). Considering India's decision to abstain from becoming a signatory to the CISG,

66 Grebler 2007, at 410-411.

67 See Art. 475 of the Brazilian Civil Code.

68 See Art. 25 of the CISG which reads: "The breach of contract committed by one of the parties is fundamental if it results in such detriment to the other party to deprive it of what it was entitled to expect under the contract, unless the party in breach did not foresee and a reasonable person of the same kind in the same circumstances would not have foreseen such a result." Also see Arts. 49, $55,64,70,72$ and 73 of the CISG, which permits the aggrieved party to terminate the contract for a fundamental breach. For a detailed discussion on the concept of "fundamental breach" under the CISG, see, generally, Ulrich G. Schroeter, Article 25 in Schlechtriem and Schwenzer on the Commentary on the UN Convention on the International Sale of Goods (CISG) 398 et seq. (I. Schwenzer (ed.), $3^{\text {rd }}$ ed., Oxford: Oxford University Press, 2010); and Chengwei Liu, The Concept of Fundamental Breach: Perspectives from the CISG, UNIDROIT Principles and PECL and Case Law, LL.M. thesis, Renmin University of China, un-paginated (May 2005).

69 See Art. 376 of the Austrian BGB.

70 See Arts. 459 and 462 of the German BGB.

71 See Arts. 401 and 385(2) of the Greek Civil Code.

72 CISG, Guide to Article 25 (Jul. 2, 2020), available at https://cisgw3.law.pace.edu.

73 Id.

74 See Grebler 2007, at 409-410.

75 See the decision of the Delhi High Court in Gas Authority of India Ltd. v. Spie Capag, S.A. \& Ors., 1993 (27) D.R.J. 562, headnote. 
disputes concerning the sale of goods ${ }^{76}$ are regulated by the Sale of Goods Act 1930 (SOGA) and the ICA. The provisions of the ICA apply to the extent that they are not inconsistent with the SOGA. An Indian court may, nonetheless, enforce the provisions of the CISG in certain international commercial disputes ${ }^{77}$ on the sale of goods. ${ }^{78}$ This would be the position if the parties to such a contract had expressly ${ }^{79}$ or impliedly ${ }^{80}$ selected the CISG as the governing law. Likewise, the CISG may also apply in the absence of a choice of law ${ }^{81}$ and the rules of private international law of the Republic lead to the application of the law of a country which has ratified the instrument. ${ }^{82}$

As indicated earlier, the non-performance of a contract constitutes every type of inability to execute the obligations of the agreement. ${ }^{83}$ The Indian law of contract is predicated on the principles of the English common law. There are two principles which regulate the consequences of non-performance of a contract for the sale of goods as well as for the sale of services - the doctrine of "frustration of contract" and the concept of a breach of contract..$^{84}$ The former regulates the consequences

76 See Sec. 2(7) of the Sale of Goods Act 1930, which defines "goods" as "every kind of moveable property other than actionable claims and money; and includes stock and shares, growing crops, grass, and things attached to or forming part of the land which are agreed to be severed before sale or under the contract of sale." Cf. Art. 366 (29A) of the Constitution ( $46^{\text {th }}$ Amendment) Act 1982 read along with Sec. 2(119) of the Central Goods and Services Tax Act 2017, which defines a "works contract" as "a contract for building, construction, fabrication, completion, erection, installation, fitting out, improvement, modification, repair, maintenance, renovation, alteration or commissioning of any immovable property wherein transfer of property in goods (whether as goods or in some other form) is involved in the execution of such contract." Also see the decision of the Supreme Court in Kone Elevator India Pvt. Ltd. v. State of Tamil Nadu and Ors. (Supreme Court), Writ Petition (C) No. 232 of 2005 dated 6 May 2014 [2014-VIL-12-SC-CB], which clarifies the difference between a contract for the sale of goods and the sale of services.

77 See Art. 2 of the CISG.

78 See Art. 3 of the CISG.

79 For a detailed discussion on the private international law of India vis-à-vis the applicable law and the express choice of the parties, see the decision of the Supreme Court in National Thermal Power Corporation v. Singer Corporation, [1992] 3 S.C.C. 551; and Saloni Khanderia, Indian Private International Law vis-à-vis Party Autonomy in the Choice of Law, 18(1) Oxford University Commonwealth Law Journal 1 (2018) [Khanderia, Party Autonomy].

80 For a detailed discussion on the private international law of India vis-à-vis the applicable law and the implied choice of the parties, see Saloni Khanderia, The Ascertainment of the Applicable Law in the Absence of Choice in India and South Africa: A Shared Future in the BRICS, 20(1) Oxford University Commonwealth Law Journal 1 (2020) [Khanderia, Applicable Law in India and South Africa].

81 For a detailed discussion on the private international law of India vis-à-vis the applicable law in the absence of choice of the parties, see Khanderia, Applicable Law in India and South Africa, supra note 80.

82 See Art. 1(b) of the CISG which reads: "This Convention applies to contracts of sale of goods between parties whose places of business are in different States (b) when the rules of private international law lead to the application of the law of a Contracting State."

83 See text accompanying notes 13-14.

${ }^{84}$ See Secs. 32, 39 and 56 of the ICA. 
of non-performance due to an unforeseen, supervening event which is outside the parties' control. ${ }^{85}$ In comparison, breach of contract generally refers to non-excused non-performance where one party has failed or refused to carry out its obligations under the contract - regardless of whether it is for the sale of goods or services. ${ }^{86}$ The doctrine of hardship has not found any place under the provisions of the Indian law on the subject. In this manner, the Indian law of contract is comparable to other common law countries discussed above, such as the UK and Australia insofar as it does not adopt a dichotomy in the solutions offered to redress non-performance due to supervening eventualities such as the outbreak of the pandemic. A party that fails to carry out its contractual obligations will, therefore, be liable for breach if the non-performance has not frustrated the contract under Indian law.

\subsection{Frustration of Contract}

Section 56 of the ICA exonerates the parties from the performance of a contract if an unforeseen impediment has rendered it impossible or "radically different from the original contemplation of the parties." ${ }^{187}$ Supervening circumstances that are caused by vis major, an act of God, the breakdown of machinery or by the occurrence of a strike are common illustrations of situations which will frustrate the contract under Indian law. ${ }^{88}$ While such impossibility need not be physical or literal, the Supreme Court has stressed that the performance of the contract should have become

useless from the point of view of the object and purpose which the parties had in view; and if an untoward event or change in circumstances totally upsets the very foundation upon which the parties rested their bargain. ${ }^{89}$

In a related vein, Section 32 of the ICA envisages that a contract would become void if its performance were contingent on the occurrence of an event and subsequently it becomes impossible for the event to happen. Accordingly, an inability to perform an international contract which is governed by the Indian law of contract due to mitigating circumstances caused by a situation such as the COVID19 outbreak would result in the "frustration" of an agreement if the occurrence of

85 Sec. 56 of the ICA.

86 Id. Sec. 39.

87 Khanderia, Commercial Impracticability, supra note 31, at 62 referring to the decision of the Supreme Court of India in Satyabrata Ghose v. Mugneeram Bangur \& Co., A.I.R. 1954 S.C. 44 [9]. Also see Nilima Bhadbhade, Pollock \& Mulla on the Indian Contract and Specific Relief Acts 871-872 (Bombay: LexisNexis, 2014); and Treitel 2014, at 64-66.

88 See the decision of the Supreme Court in Dhanrajamal Gobindram v. Shamji Kalidas \& Co, A.I.R. 1961 S.C. 1285 [17-19].

89 See the decision of the Supreme Court of India in Satyabrata Ghose, supra note 87, at [9]; and Khanderia, Commercial Impracticability, supra note 31, at 63. 
the pandemic was supervening, unforeseeable and destroyed the very purpose of the transaction. In other words, the parties to an international contract which has been concluded after the outbreak of the COVID-19 pandemic would not be able to successfully rely on the defence of "frustration" since its occurrence was no longer unforeseeable. In such circumstances, the aggrieved party may sue the party in default for a breach of contract under Indian law.

The impact of hardship on non-performance

According to Section 56 of the ICA, a mere change in the price of the performance due to supervening situations such as the COVID-19 pandemic would not suffice in frustrating the contract unless it renders the implementation of the obligations impossible at the time and in the manner contemplated by the parties. ${ }^{90} \mathrm{Clarifying}$ the application of the doctrine of "frustration of contract," the Supreme Court in Alopi Parshad \& Sons Ltd. v. Union of India, when called upon to determine whether the increase in the price of ghee (i.e. clarified butter) caused by the Second World War rendered the performance impossible, explained that such a supervening change in circumstances would not be construed as an impossible act if its occurrence does not affect the bargain made by the parties. ${ }^{91}$ The Supreme Court's decision in Alopi Parshad remains the current position under the Indian law of contract and has been reiterated in a plethora of judicial dicta. ${ }^{92}$

The validity of force majeure clauses under Section 56

Most agreements contain a force majeure clause which allows the parties to be excused from performance on the occurrence of certain unforeseen impediments such as war, strike, earthquakes and epidemics - provided that these have been identified in the agreement. The court will strictly construe the terms of the force majeure clause. It will permit the parties to terminate the contract due to the occurrence of an impossible event if the force majeure clause explicitly provides for the same. The decision of the Bombay High Court in Standard Retail v. GS Global ${ }^{33}$ succinctly illustrates this point. The petitioner (an importer of steel) sought to be excused from performing its contractual obligations towards a third party (a bank), i.e. from encashing the letters of credit in favour of the respondent (a corporation in the steel business) due to the outbreak of COVID-19 and the resultant national lockdown in India. ${ }^{94}$ However, the terms of the contract merely permitted the respondent (and not the petitioner) to invoke the force majeure clause if an unforeseen event

90

Satyabrata Ghose, supra note 87, at [9]. Also see Sachindra Nath v. Gopal Chandra, A.I.R. 1949 Cal. 240; Pameshwari Das Mehra v. Ram Chand Om Prakash, A.I.R. 1952 Punj. 34.

91

92

93

94 Id. 
such as a pandemic has hindered the performance. ${ }^{95}$ The respondent, on the other hand, had successfully fulfilled its obligations despite the COVID-19 outbreak in South Korea. ${ }^{96}$ The court held that the fact that the petitioner was unable to fulfil its obligations concerning its purchases could not be considered since the respondent had complied with its part under the contract. ${ }^{97}$

In addition to permitting the parties to terminate the contract due to the occurrence of impossible events, the terms of some of these clauses may allow the parties to be discharged from liability if the obligation has become onerous to perform as a result of an unforeseen impediment.

Consider the following scenario. An Italian seller and an Indian buyer conclude a contract on 1 April 2020 for the sale of ten wedding gowns to be delivered in New Delhi on or before noon (IST) 25 July 2020. However, the outbreak of the COVID-19 pandemic has caused the price of silk to increase by ten times - from a rate of Euros 1,000 per quintal to Euros 10,000 per quintal due to enhanced border controls which have increased the cost of transportation. The agreement contains a force majeure clause which permits the parties to terminate the contract if an unforeseen impediment renders the contract more onerous to perform. The seller is unable to perform at the contracted price. The buyer sues the seller before the Indian court for non-performance.

An examination of judicial dicta demonstrates the trend that the courts in India will invalidate a force majeure clause in the parties' agreement if it permits the parties to terminate the contract for anything less than frustration and impossibility to perform under Section 56 of the ICA. ${ }^{98}$

The judicial interpretation attached to force majeure clauses has, however, been far from uniform. ${ }^{99}$ In Coastal Andhra Power Ltd. v. Andhra Pradesh Central Power Distribution Co. Ltd. \& Others, the Delhi High Court refused to regard as "frustration" an escalation in the price of coal by 150 per cent due to the promulgation of an Indonesian Regulation after the conclusion of the contract even though the terms expressly permitted the parties to be discharged from liability if a supervening circumstance in the form of a force majeure event "prevented, hindered or delayed" performance due to the change in the cost of materials. ${ }^{100}$ However, in Uttar Haryana Bijli Vitran Nigam Ltd. v. Central Electricity Regulatory Commission, the Appellate Tribunal for Electricity, New Delhi (the Tribunal) decided to regard as a force majeure event an increase in the price of coal due to the Indonesian Regulation in a subsequent dispute with a similar set of facts. ${ }^{101}$

\footnotetext{
95 Commercial Arbitration Petition (L) No. 404 of 2020 [3].

96 Id.

97 Id. [4].

98 Decision of the Delhi High Court, OMP No. 267 of 2012 (decided on 2 July 2012) [5, 7, 8, 24].

99 See Khanderia, Commercial Impracticability, supra note 31, at 64 et seq.

100 Id. at 65, referring to Coastal Andhra Power Limited, at [5, 7, 8, 24].

101 See Decision of the Appellate Tribunal for Electricity, decided on 7 April 2016.
} 
In a more recent decision, the Supreme Court in South East Asia Marine Engineering and Constructions Ltd. v. Oil India Ltd. confirmed that the contents of a force majeure clause must coincide with the parameters stipulated under Section 56 of the ICA which "lays down a rule of positive law and does not leave the matter to be determined by the parties. ${ }^{112}$ The dictum in South East Asia Marine ${ }^{103}$ is binding by the mandate espoused under Article 141 of the Constitution of India which states that "the law declared by the Supreme Court shall be binding on all courts within the territory."

While several other major legal systems and, in particular, civil law jurisdictions permit the parties to renegotiate the terms of the contract to accommodate to changed circumstances, ${ }_{10}^{104}$ Indian law does not make any similar provision. ${ }^{105}$ The Supreme Court in South East Asia Marine Engineering ${ }^{106}$ explicitly rejected the validity of "habendum clauses" which permit the parties to renegotiate the terms of the agreement to adapt to changing circumstances which impact the price of the performance. ${ }^{107}$ In such circumstances, the parties may, however, ameliorate the "harshness" of the doctrine of frustration of contract by restoring the benefit that they had received under the agreement when it became void. ${ }^{108}$

That said, the parties' inability to perform a contract, which is governed by the Indian law, according to the original terms of the agreement on account of hardship caused due to the occurrence of the COVID-19 pandemic will be regarded as a breach of contract unless they have agreed to novate the contract under Section 62 of the Indian Contract Act 1872 by substituting it with a new agreement.

\subsection{Breach of Contract}

As indicated earlier, the consequences of a breach under Indian law depend on whether the non-performance relates to a contract for the sale of goods or services.

Contracts for the sale of goods

Unlike the provisions of the $\mathrm{CISG}_{1}{ }^{109}$ the SOGA does not explicitly entitle a party to terminate a contract for fundamental breach. However, a close examination of the provisions of the SOGA and the judicial dicta on the subject demonstrates that

1022020 S.C.C. Online 451 [23]. Also see Energy Watchdog v. Central Electricity Regulatory Commission \& Ors., [2017] 12 S.C.C. 80 [34].

Supra note 102.

See text accompanying notes 22-38.

See Khanderia, Commercial Impracticability, supra note 31, at 62 et seq.

Supra note 102.

Id. [18].

Id. [23] referring to Sec. 65 of the ICA.

See Art. 25 of the CISG read along with Arts. 49, 55, 64, 70, 72 and 73 of the CISG, which permits the aggrieved party to terminate the contract for a fundamental breach. 
Indian law on the subject resonates with that in Austria ${ }^{110}$ and Germany ${ }^{111}$ by not adopting a unitary concept of a breach of contract. Contracts on the sale of goods which are governed by Indian law may exclusively be terminated on account of the occurrence of material as opposed to minor circumstances.

Under Indian law, the concept of breach of an international contract on the sale of goods is predicated on the English common law. The consequences of breach hinge on the so-called condition/warranty dichotomy. ${ }^{112}$ It is not every breach which would entitle the aggrieved party to terminate an international contract; rather, it is a breach of a "condition" which would give the right to the aggrieved party to treat the contract as repudiated and sue the defaulting party for damages. ${ }^{113}$ The breach of a "warranty," on the other hand, would merely give rise to a claim for damages. ${ }^{114}$ The aggrieved party may, however, elect to treat the breach of a "condition" as that of a "warranty" and, thus, merely sue for damages as opposed to terminating the contract. ${ }^{115}$

The statute defines a "condition" to mean a clause in a contract which may be regarded as "essential to the main purpose."116 Judicial dicta demonstrate that the interpretation of the term "essential" is synonymous to a "fundamental" breach insofar as it goes to the root of the contract and substantially deprives the aggrieved party of what it was entitled to expect. ${ }^{17}$ The promise must, therefore, be "of such importance" to the aggrieved party "that it could not have entered into the contract without an assurance of strict or substantial performance of the contract."118 $\mathrm{A}$ "warranty," on the other hand, has been defined as a stipulation in a contract which is "collateral" to its primary purpose. ${ }^{119}$ The courts have held that a clause in an agreement where one party agrees to supply a certain product such as a power plant of $108 \mathrm{MW}$ would constitute a "condition" by forming the essence of the contract. ${ }^{120}$ In comparison,

110 See Art. 376 of the Austrian BGB; and text accompanying notes 66-67.

111 See Arts. 459 and 462 of the German BGB; and text accompanying notes 66-67.

112 Darren Peacock, Avoidance and the Notion of Fundamental Breach under the CISG: An English Perspective, 8 International Trade \& Business Law Annual 95, 107 (2003), referring to the concept of concept of "conditions" and "warranties" under the English Sale of Goods Act, 1979.

113 Sec. 12(2) of the SOGA. Also see Antony Thomas v. Ayuppunni Mani, A.I.R. 1960 Ker. 176; Commissioner of Sales Tax v. Ms. Prem Nath Motors (P) Ltd., I.L.R. (1978) II Delhi; and Calicut Engineering Works (P) Ltd. v. Batliboi Ltd., (2007) 1 Cal. L.T. 466.

114 Id. Sec. 12(3).

115 Id. Sec. 13(1).

116 Id. Sec. 12(2); and Antony Thomas, supra note 113, at [4] referring to Moulton L.J. in the decision of the English court in Wallis, Son and Wells v. Pratt, (1910) 2 K.B. 1003.

117 See Calicut Engineering Works, supra note 113, at [15].

118 Id.

119 Sec. $12(3)$ of the SOGA.

120 See Svenska Handelsbanken v. Ms. Indian Charge Chrome \& Ors., (1994) S.C.C. 502. 
a clause in an agreement for the sale of goods which obligates the seller to repair any defect in the goods after the performance ${ }^{121}$ would be construed as a "warranty"insofar as its breach does not substantially deprive the aggrieved party of its entitlements under the contract. ${ }^{122}$

In certain circumstances, however, the breach of an essential clause may not have already taken place. Nonetheless, its occurrence may be so evident to the aggrieved party before the date of performance to give it a reasonable ground to believe that the other party is no longer able or willing to carry out its obligations. In such scenarios, the aggrieved party may terminate the contract for anticipatory breach and sue for damages. To illustrate, consider the scenario indicated earlier in the contract for the sale of wedding gowns between the Italian seller and the Indian buyer. The parties agree that the products will be delivered in New Delhi on or before noon (IST) 25 April 2020 . The agreement contains a clause specifying the parties' intentions that time is the essence of the contract. The clause in the particular case will be treated as a "condition" by explicitly being made the "essence of the contract" under Section 12 of the legislation.

Further assume that at 7 p.m. (IST) on 25 April 2020 (the day before the proposed delivery) the seller informs the buyer that the goods are being loaded onboard a ship from the port of Rome to Mumbai; after which, they will be delivered to New Delhi by air. If Indian law governs the contract, the buyer, in the present case, may opt to terminate the contract for anticipatory breach since the non-fulfilment has become evident and is not due to an unforeseen, supervening event. The buyer may alternatively choose to wait until the time of performance has passed and sue the seller for termination and damages.

That said, whether or not a clause may be construed as "essential to the main purpose" of the contract will depend on its construction as indicated in the terms of the agreement. ${ }^{123}$ In some instances, the parties may explicitly state a stipulation as "essential" in the terms of their contract. In contrast, in others a clause may implicitly form the essence of the contract and, thus, assume the character of a "condition"124 in the absence of any express indication to the contrary. ${ }^{125}$

A clause in a contract would be construed as an implied "condition" under the Indian law in the following circumstances:

i) when the contract has been concluded by sharing a description of the goods. Sections 15 and 16(2) of the Sale of Goods Act 1930 impose an obligation on the

\footnotetext{
121 See Indochem Electronic \& Anr. v. Additional Collector of Customs, A.P., (2006) S.C.C. 721.

122 Id.

123 Sec. $12(4)$ of the SOGA.

124 Id. Secs. 14-17.

125 Id. Secs. 16(4) and 62. Also see Dinshah F. Mulla, Mulla on the Sale of Goods Act and the Indian Partnership Act 39, 139-140 (10 ${ }^{\text {th }}$ ed., Delhi: Lexis Nexis, 2012).
} 
seller to ensure that the product(s) conform accurately with the explanation given in the terms ${ }^{126}$ and are of "merchantable quality." ${ }^{127}$ Judicial dicta indicate that every item in a contract which has been concluded on the description of the product will "constitute a substantial ingredient in the identity of the thing sold" and will thus be construed as a "condition."128 Therefore, the "failure to secure [an] exact conformity to the full contractual description" will render the product as not being the "article bargained for." ${ }^{\prime \prime 29}$

ii) when the contract has been concluded by a sample of the product. Section 15 further imposes an obligation on the seller to ensure that the specimen(s) correspond with the bulk in terms of quality and be free of any defects so as not to render the products "unmerchantable." ${ }^{130}$ In certain circumstances, however, where the contract for the sale of goods has been concluded based on a description and a sample, the adherence of the product with the description will be construed as the "essence of the contract.".131 In other words, the mere conformity to the sample would not suffice. ${ }^{132}$

iii) when there is an assurance as to the quality or fitness of the product. In general, assertions made by the seller as regards the quality or the fitness of the product would not form an implied condition or warranty under Section 16 of the statute due to the application of the common law doctrine of caveat emptor in India. In certain circumstances, however, an assurance concerning the quality or fitness of a product may assume the status of an implied condition when the buyer indicates explicitly

the particular purpose for which, the goods are required, to show that s/ he relies on the seller's skill or judgment, and ... are of the description which are in the (latter's) course of business to supply. ${ }^{133}$

By this principle, a defect in a hot-water bottle in a contract of sale by a pharmacist will be construed as forming the essence of the agreement to hold the seller liable for breach and damages if the product burns and injures the buyer by being unable to sustain hot water. ${ }^{134}$

\footnotetext{
Sec. 15 of the SOGA.

Id. Sec. 16(2). Also see Mulla, supra note 125, at 48-50.

Calicut Engineering Works, supra note 113, at [13], referring to the verdict of the King's Bench in Couchman v. Hill, (1947) K.B. 554, 559. Id. [13]; SH Joshi \& Co. v. VM Ismail, A.I.R. 1960 Mad. 520; and Antony Thomas, supra note 113, at [8]. Sec. 15 of the SOGA. Id.; and Calicut Engineering Works, supra note 113, at [13].

132 Id.

133 Sec. 16(1) of the SOGA.

134 Mulla, supra note 125 , at $43-47$.
} 
iv) when there is a stipulation as to the time of delivery. Although there is no express provision to this effect, judicial dicta demonstrate that the time of delivery will also be construed as forming the essence of the contract especially in ordinary commercial contracts for the sale of goods regardless of whether or not there is a stipulation in the contract to this effect. . $^{135}$ The "speculative value"136 and "galloping inflation"137 which such contracts are susceptible to will render the failure to perform "at or before such time"138 indicated in the parties' agreement as a breach which goes to the "root of the contract."139

All other forms of breach in a contract for the international sale of goods which are governed by the Indian law would merely entitle the aggrieved party to damages as opposed to the right to termination. This will be the position where the buyer wrongfully neglects or refuses to accept and pay for the goods - regardless of whether the property has passed or not. ${ }^{140}$ In such circumstances, the seller's only right would be to withhold the products on lien ${ }^{141}$ and sue the buyer for the price of the goods ${ }^{142}$ and demand damages. ${ }^{143}$ Neither the SOGA nor the existing dicta sufficiently indicate whether such a breach (on the part of the buyer) would be regarded as a violation of a "condition" or a "warranty."Thus, while the seller's right to receive payment upon delivery should generally be interpreted as being "essential to the main purpose of the contract," Section 11 of the statute states otherwise. Therefore, while stipulations as to the time of delivery may constitute a condition, those for the time of payment would not per se be "deemed to be the essence of the contract" in a contract for the sale of goods which is governed by Indian law. ${ }^{144}$ In this manner, Indian law adopts an asymmetrical approach in defining the rights of buyers and sellers in contracts for the sale of goods.

Contracts for the sale of services

In the absence of any international convention or special statute to regulate the sale of services, the provisions of the ICA regulate all cross-border disputes arising in connection to a contract for the sale of services which is governed by Indian law.

135 See Lucknow Automobiles v. Replacement Parts Co, A.I.R. 1940 Oudh. 443; Mahabir Prasad Rungta v. Durga Dutta, A.I.R. 1957 Pat. 586; Venkateshwara Minerals Firm v. Jugalkishore Chiranjitlal Firm, A.I.R. 1986 Kant. 14; and Citadel Fine Pharmaceuticals v. Ramaniyam Real Estates Pvt Ltd., Civil Appeal No. 6437 of 2011.

See Citadel Fine Pharmaceuticals, supra note 135, at [42].

See Saradamini Kandappan v S Rajalakshmi \& Ors., (2011) 12 S.C.C. 8.

See Sec. 55 para 1 of the ICA.

Id.

Id. Secs. 55 and 56.

See Secs. 45-54 of the SOGA, which discuss the unpaid seller's right to lien.

Id. Sec. 55(1).

Id. Sec. 56.

Sec. 11 of the SOGA. 
The ICA does not explicitly employ the term "fundamental breach" as a benchmark to ascertain the rights and liabilities of the parties. In this manner, the approach of the ICA is similar to that adopted under the SOGA. However, the concept of fundamental breach under the ICA is a "fragmented" one and has been indirectly dealt with under Sections 39 and 53 to 55 of the ICA. The judicial interpretation attached to each of these provisions sufficiently indicates that the decision to terminate such a contract for breach will depend, in principle, on whether or not the failure to perform was "substantial" or "fundamental."155 The term "substantial" has, in turn, metaphorically been described as that (breach) "which goes to the root of the contract."1 ${ }^{\prime 16}$ In other words, and as the courts have indicated, a party will be considered to have "substantially" breached a contract governed by the ICA when it has violated a "basic, main term of an agreement, so primary that upon such breach, the other reciprocal promises cannot be performed by the other party to the contract."147

A breach of a contract for the sale of services will be considered to be "substantial" in the following circumstances:

i) when "words or conduct,"148 "a party to a contract has refused to perform or disabled himself from performing, his promise in its entirety..$^{\text {m49 }}$ Such a breach would be considered to be "substantial" under Section 39 of the ICA provided that there has been an absolute or anticipatory failure to perform..$^{150}$

The employment of the phrase "in its entirety" indicates that the parameters of the provision are limited to substantial breaches in contracts, ${ }_{151}^{151}$ which are executory that is, those where the time of performance has not yet arrived. ${ }^{152}$ For this reason, defective non-performance will not be construed as "substantial" for the reason that

145 See Madhya Pradesh Rural Road Development Authority \& Another v. LG Chaudhary Engineers \& Contractors, (2012) 3 S.C.C. 495, referring to the landmark judgment of the House of Lords in Photo Production v. Securicor Ltd., [1980] A.C. 827 (H.L.), 848-852; Maharastra State Electricity Board \& Anr. v. Datar Switchgear \& Anr., 2005 S.C.C. Online Bom; Public Works Department v. Ms. Navayuga Engineering Co. Ltd. \& Anr., 2014 S.C.C. Online Del. 1343; and Maharashtra State Electricity Distribution v. DSL Enterprises Pvt. Ltd., (2009) 4 Bom. C.R. 843.

See M/s Classic Motors Ltd. v. Maruti Udhyog Ltd., 1997 I.A.D. Delhi 190; Public Works, supra note 145, at [41]; and Maharashtra State Electricity Distribution, supra note 135, at [53]. Maharashtra State Electricity, supra note 135, at [48].

See Om Prakash Baldve Kishan v. U.O.I. \& Another, FAO (OS) No. 14 of 1980 \& FAO (OS) No. 32 of 1980 [11]; Federal Commerce and Navigation Ltd. v. Molena Alpha Ltd., [1979] AC 757; and Bhadbhade, supra note 87 , at 779 .

Sec. 39 of the ICA.

150 Bhadbhade, supra note 87 , at 778-788.

151 See Madhya Pradesh Rural Road, supra note 146.

See Public Works, supra note 135, at [41]; and Maharashtra State Electricity Distribution, supra note 135 , at [53].

152 Bhadbhade, supra note 87 , at 778 
the contractual obligations have already been executed. ${ }^{153}$ Academic and scholarly writings indicate that for a contract to be breached "in its entirety" it must be clear that the party in default has violated an essential term of the contract in a manner that prevents "the promisee from getting in substance, what he had bargained for." ${ }^{\prime 154}$ In some circumstances, however, the party in default may evince its intention of being unwilling to carry out its obligations before the date of performance, in which case, the breach would be anticipatory. ${ }^{155}$

Interpreting the parameters of Section 39, the Supreme Court in Madhya Pradesh Rural Road Development Authority \& Another v. LG Chaudhary Engineers \& Contractors stated that a violation of a term which is considered to be essential depends on when the party in default has failed to perform a clause which has explicitly been classified as "fundamental" in the agreement. ${ }^{156}$ In other scenarios, when the terms of the contract do not categorise any term as "essential," its interpretation would depend on whether the breach has "deprive[d] the innocent party of substantially the whole benefit of which it was the intention of the parties that was expressed in the contract."157

Such violations will be regarded as "substantial" regardless of an "exclusion clause" in the parties' contract indicating to the contrary. ${ }^{158}$ For this reason, the failure to provide the list of locations to install electricity poles by one party to another will be considered to be "substantial" under Section 39. ${ }^{159}$

ii) when one party adversely affects the performance of "reciprocal promises" in some manner. As such, "reciprocal promises" rest on the duty to cooperate ${ }^{160}$ and are defined as those "which form the consideration or part of the consideration for each other." ${ }^{161}$ In other words, reciprocal promises are those which are so intertwined with one another that they cannot be performed unless each party simultaneously observes its contractual obligations. A requirement to provide the list of locations for the installation of electricity poles ${ }^{162}$ is an illustration of a "reciprocal promise" in a services contract. At present, there are no judicial dicta that categorise a breach of a reciprocal promise as "fundamental" or "substantial." Nonetheless, a close

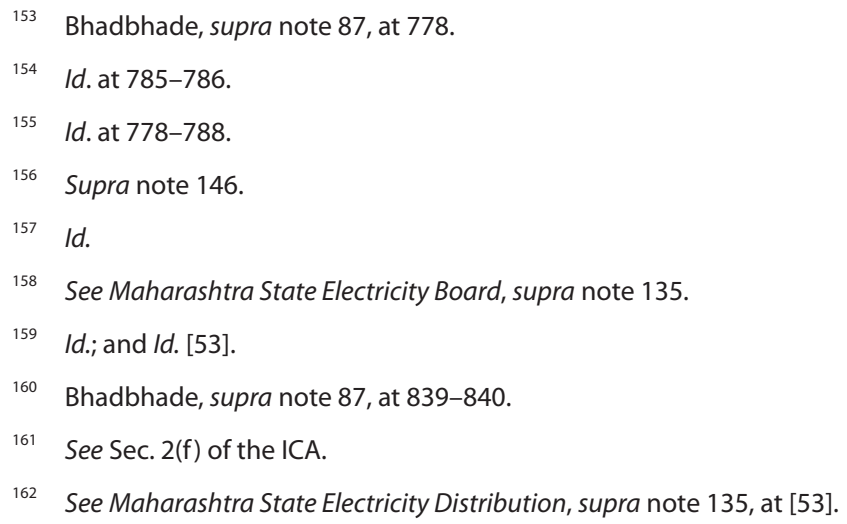


examination of the parameters of Sections 53 and 54 indicate that such breaches will be perceived as going to the root of the contract.

A breach will be substantial under the purview of Section 53 if one party has wrongfully prevented the other from performing its obligations or has obstructed"the event on which the contract is to take effect" by "putting an end to the circumstances on the continuance of which the contract rests." ${ }^{163}$ The employment of the term "wrongful" indicates that the prevention - regardless of whether it is express, implied or independent of contract, ${ }^{164}$ must be proactive and of such a nature that it hinders the innocent party's timely completion of the contract. ${ }^{1.5}$ To illustrate, the failure of the owner of a construction venue to provide access to a builder during the tenure when the work was to commence would be construed as "wrongful prevention" and substantial if the builder is unable to complete the project within the agreed timeline. A few days of delay in providing access would not be regarded as "substantial" if it did not hinder a timely performance, since it does not go to the root of the contract; and therefore it would not fall within the purview of Section 53.

In some contracts, the order of obligations is such that "its performance cannot be claimed till the other has been performed."166 Such obligations need to be entirely performed by one party before the other can observe its reciprocal promise. ${ }^{167}$ The failure (as opposed to "prevention" under Section 53) to carry out the obligations by one party to the detriment of another would, consequently, amount to a substantial breach under Section 54 of the Indian Contract Act 1872. The failure to clear the land of clear waste by one party to a contract to enable a builder to fulfil its obligations to construct on that land serves as an illustration of a substantial breach of a reciprocal promise under Section 54.

iii) when the parties have expressly or impliedly agreed that time would be the essence of the agreement. According to the terms of Section 55 of the ICA, an agreement may specifically include a clause to indicate the parties' intention to regard the time of performance as the paramount importance; or the same may be gathered from the nature and circumstances of the case. ${ }^{168} \mathrm{~A}$ contract with a courier-agency for "express" or "expedited" delivery as opposed to standard delivery is an express indication that

163 Bhadbhade, supra note 87 , at 839 . Sec. 53 of the ICA provides: "When a contract contains reciprocal promises and one party to the contract prevents the other from performing his promise, the contract becomes voidable at the option of the party so prevented; and he is entitled to compensation from the other party for any loss which he may sustain in consequence of the non-performance of the contract."

Bhadbhade, supra note 87 , at 839 .

Id. at 839-840.

See Sec. 54 of the ICA.

Bhadbhade, supra note 87 , at 844 .

Citadel Fine Pharmaceuticals, supra note 135, at [38]. Also see Bhadbhade, supra note 87, at 849-853. 
time is of the essence of the contract. Likewise, an agreement with an architect to conclude the renovation of a showroom before a specific date would impliedly render time as the essence of the contract if the fact of the ceremony of the "opening" of the store on the following day has been made known to him.

Unlike in an agreement for the sale of goods, stipulations as to the time of payment will not be regarded on a different footing in a services contract which is governed by Indian law. ${ }^{169}$ In other words, in some situations, depending on the terms of the parties' agreement, the time of payment can per se be regarded as the essence for the sale of services under Section 55 of the ICA. The Supreme Court's decision in Mahabir Prasad Rungta v. Durga Dutta succinctly illustrates this point. The dispute in question concerned a transportation contract between a colliery owner and a carriage service provider to carry coal which contained a stipulation that payment would be made on the $10^{\text {th }}$ day of every month. ${ }^{170}$ It was held that time of payment was the essence of such an agreement and the failure to pay on the due date or within a reasonable duration thereafter would attract the provisions of Section 55 since the transportation company could not be expected to fulfil its obligations without the same. ${ }^{171}$

Yet, not every "express" indication to this effect in an agreement governed by the Indian law will render time as the essence of the contract. The Privy Council as early as 1915 clarified that:

The mere fixation of a period within which, the contract may have to be performed also does not make any such stipulation as to the essence of the contract. The intention to treat time as the essence of the contract may, however, be evidenced by circumstances that are strong enough to displace the initial presumption. Even a stipulation in the agreement that time is the essence of the contract has to be read along with other provisions of the contract to determine whether the completion of the transaction within the time specified was intended to be a fundamental requirement. ${ }^{172}$

Similar to contracts for the sale of goods, time will ordinarily be presumed to be of the essence in commercial contracts that concern services in the absence of a contrary indication to this effect. ${ }^{173}$ The courts in India have, accordingly, refused to

See Sec. 11 of the SOGA discussed in the text accompanying notes 135-144.

170 A.I.R. 1961 S.C. 990.

171 Id. [8].

172 Jamshed Khodaram Irani v. Burjorji Dhunjibhai, A.I.R. 1915 Privy Council 83.

173 See the decisions of the courts in The Phoenix Mills Ltd. v. Madhavdas Rupchand, (1922) 24 B.O.M.L.R. 142; Lucknow Automobiles v. Replacement Parts Co, A.I.R. 1940 Oudh. 443; Mahabir Prasad Rungta v. Durga Dutta, A.I.R. 1957 Pat. 586; China Cotton Exporters v. Beharilal Ramcharan Cotton Mills Ltd., 1961 A.I.R. 1295; Venkateshwara Minerals Firm v. Jugalkishore Chiranjitlal Firm, A.I.R. 1986 Kant. 14; Arosan 
entertain allegations of fundamental breach in contracts where time has expressly been made the essence but contain explicit provisions for the extension of time..$^{174}$ In such circumstances, it has been held that the words "time is the essence of the contract" is not of much consequence..$^{175}$ Likewise, contracts with clauses for the payment of penalty or fine for every day or week of delay will not fall within the purview of Section 55 having regard to the "real intentions"176 of the parties which indicate otherwise. ${ }^{177}$

\section{Consequences of termination for the breach of an "essential clause"}

The breach of an essential clause is tantamount to a fundamental breach under Indian law. The provisions of the ICA regulate the consequences of such breach regardless of whether it relates to the sale of goods or services.

The breach of an essential clause does not result in the automatic termination of the contract. The aggrieved party must exercise its right to rescind the contract and sue for termination and damages by giving notice to the party in default of its intention to do so. ${ }^{178}$ In doing so, the parties must, however, restore "so far as may be" possible any benefit that they may have "hitherto enjoyed under the contract."179

The party that has failed or refused to perform an essential stipulation is, however, merely liable for any direct damage ${ }^{180}$ that the aggrieved party has suffered as a consequence of the non-performance. ${ }^{181}$ For this reason, the damages for such breach will be restricted to the loss, including loss of profit, that occurred naturally in the usual course of events, the result of which was foreseeable as the

Enterprises Ltd. v. Union of India and Another, (1999) 9 S.C.C. 449; Shriram Pistons \& Rings Ltd. v. Buckeye Machines (P) Ltd., 136 (2007) D.L.T. 254; and Citadel Fine Pharmaceuticals, supra note 135.

174 See Hind Construction Contractors v. The State of Maharashtra, 1979 A.I.R. 720; Oil \& Natural Gas Corporation Ltd. (ONGC) v. Astra Construction Pvt. Ltd., 2012 (5) G.L.T. 616.

175 Hind Construction Contractors, supra note 174.

176 See Citadel Fine Pharmaceuticals, supra note 135, at [38]. Also see Bhadbhade, supra note 87, at 850-851.

177 See Chand Rani v. Kamal Rani, (1993) 1 S.C.C. 519; and Citadel Fine Pharmaceuticals, supra note, 135 at [46]. Also see Bhadbhade, supra note 87 , at 860.

178 See Sec. 66 of the ICA which provides: "The rescission of a voidable contract may be communicated or revoked in the same manner, and subject to the same rules, as apply to the communication or revocation of the proposal."

179 See Sec. 64 of the ICA which provides: "When a person at whose option a contract is voidable rescinds it, the other party thereto need not perform any promise therein contained in which he is the promisor. The party rescinding a voidable contract shall, if he had received any benefit thereunder from another party to such contract, restore such benefit, so far as may be, to the person from whom it was received."

180 See Bhadbhade, supra note 87, at 1155 which defines the term "damage" as "the disadvantage, which is suffered by a person as a result of the act or default of another."

181 See the decision of the Supreme Court in Pannalal Jankidas v. Mohanlal, A.I.R. 1951 S.C. 144, 153, referring to the dictum of the English court in Hadley v. Baxendale, (1854) 9 Exch. 341. Also see Avatar Singh, Law of Contract and Specific Relief 474 (12 ${ }^{\text {th }}$ ed., Lucknow: Eastern Book Company, 2018). 
likely consequence of such non-performance at the time of the conclusion of the contract. ${ }^{182}$ As a result, the courts in India have expressed some reluctance in granting damages for loss in the form of mental pain and suffering especially in commercial contracts insofar as such loss is not construed as "direct" or pecuniary. ${ }^{183}$

In certain circumstances, the parties may have expressly indicated a sum to be payable or made a provision for the forfeiture of earnest money in the event of such breach. ${ }^{184}$ In such scenarios, Indian law empowers the court to award the aggrieved party compensation not exceeding the amount stipulated in the contract or permit the forfeiture of money, regardless of whether or not the party suffered actual damage or loss. ${ }^{185}$ In contracts for the sale of services, the right to such compensation is restricted for breach of contracts where time has been made the essence..$^{186}$ In such circumstances, Indian law does not permit the innocent party to claim compensation while exercising its right to rescind the agreement if it has accepted performance at any other time than that agreed. ${ }^{187}$

The means which existed to mitigate such loss will play a crucial role while calculating the quantum of damages, ${ }^{188}$ especially in contracts for the sale of goods. ${ }^{189}$ The courts have, therefore, stressed the obligation of the aggrieved seller to make every attempt to resell the products before claiming damages in a suit against a buyer that fails to take delivery. ${ }^{100}$ Likewise, the buyer in a lawsuit against the seller for non-delivery is under the onus to take every initiative to procure the goods from another seller before claiming damages.

The quantum of damages for breach of such contracts will then be calculated based on the difference between the contract price of the product and the hypothetical market price..$^{191}$ In other words, the courts will merely consider the value of the good(s) in the market to calculate the damages at the time of termination;

182 Sec. 73 of the ICA. Also see Singh, supra note 181, at 477-481.

183 See Bangalore Development Authority v. Syndicate Bank, (2007) 6 S.C.C. 711 and Singh, supra note, at 502-504.

184 See the decisions of the Supreme Court of India in Fatehchand v. Balkishan Das [1964] 1 S.C.R. 515; Maula Bux v. Union of India [1969] 2 S.C.C. 554; and Oil and Natural Gas Corporation v. Saw Pipes [2003] 5 S.C.C. 705.

185 Id.

186 See Sec. 55 para 3 of the ICA.

187 Id.

188 See Explanation to Sec. 73 of the ICA which reads: "In estimating the loss or damage arising from a breach of contract, the means which existed of remedying the inconvenience caused by non-performance of the contract must be taken into account." Also see Singh, supra note 181, at 520. Singh, supra note 181, at 520. AKAS Jamal v. Moola Dawood Sons \& Co., I.L.R. (1916) 43 Cal. 493. Also see Singh, supra note 181, at 520.

191 See Murliadhar Chiranjilalv. Harishchandra Dwarkadas, A.I.R. 1962 S.C. 366. Also see Singh, supra note 181, at 482-484. 
and the party does not need to buy or sell the product (as the case may be) ${ }^{192}$ To illustrate, the court will consider the seller's compulsion to trade the good(s) at a lower price on the buyer's failure to accept delivery; or the buyer's urgency to purchase the product at a higher value when the obligations are not performed as per the contractual terms.

\section{Predicaments in Applying Indian Law to Transnational Contracts Arising from Non-Performance as a Result of COVID-19}

The fact that there is no reported case in which the parties to any international contract have chosen to be governed by Indian law speaks volumes about the individual perceptions concerning the ability of the legal principles on the subject in this country to deal with complex claims. Unlike the laws of major jurisdictions such as France, Austria, Italy, Greece, China and the United States, but also soft law in the form of the UNIDROIT Principles of International Commercial Contracts, which are well equipped to deal with uncertainties in terms of the performance of the contract becoming more onerous as a result of the COVID-19 outbreak, ${ }^{193}$ Indian law provides no respite in this regard. The trend among civil law countries such as France, Italy, Austria, Germany, the Netherlands, Greece and China have been to permit the parties to renegotiate the terms to accommodate to changed circumstances ${ }^{194}$ The courts in these countries permit the parties to terminate the contract for hardship only if renegotiation was not possible. ${ }^{195}$ Although the law of the United States does not permit such renegotiation, it, nonetheless, provides some respite to the parties by exonerating them from performance. ${ }^{196}$

In comparison, Indian law prevents access to justice by failing to acknowledge unforeseen, supervening circumstances which result in dramatic price fluctuations. Even force majeure clauses which are concluded by the free will of the parties, and which attempt to excuse the parties from performing contracts that have become more onerous and have fundamentally altered their equilibrium, will be invalidated under Indian law. Instead, the parties must mandatorily conclude a new contract by agreeing to terminate the existing agreement. ${ }^{197}$ In this manner, Indian law provides the parties with two drastic solutions. Under the first option, the party that

\footnotetext{
192 See Union of India v. Commercial Metal Corporation, A.I.R. 1982 Del. 267. Also see Singh, supra note 181, at 484 .

193 See text accompanying notes $22-38$.

194 Id

195 Id

196 See text accompanying notes 47-49.

197 See Sec. 62 of the ICA.
} 
is adversely affected by the change in circumstance is compelled to perform the contract according to the original terms. Under the second option, the party that is adversely affected faces the risk of being sued for breach of contract if it decides that it cannot perform the contract according to the original terms and the other party chooses not to conclude a new contract.

The provisions on breach of contract are convoluted and require the parties to familiarise themselves with them to gauge the type of obligation that was violated. The comparative analysis of the legislation reveals the "sheer complexity and entangled interaction ${ }^{\prime 1198}$ between the provisions of the ICA and the SOGA on breach. The SOGA considers defective performance to be material if it was a violation of a "condition." In comparison, the ICA does not consider defective performance to be material, ${ }^{199}$ and the aggrieved party may merely sue for damages, but not for termination of the contract. On the other hand, the ICA does not adopt an asymmetrical approach as the SOGA does, and it provides the seller and the buyer with equal rights to sue for fundamental breach and the consequent termination of the contract.

\section{Conclusion}

Epidemics and pandemics such as COVID-19 have impacted the fabric of societies throughout history in a number of ways. Among other things, such incidents compel lawmakers to evaluate whether the legal principles applicable in their country are equipped to deal with the disputes that these outbreaks bring with them. Such disputes are likely to be complex because they require the judiciary to adjudicate upon the validity of (a) the force majeure certificates that may be provided by the governments of other countries and (b) their own force majeure clauses; and (c) to determine whether the pandemic can even be regarded as an unforeseen, supervening eventuality.

The discussion offered in this paper indicates that the theoretical structure of the Indian law of contract renders it incomprehensible and unsuitable to govern domestic agreements, let alone transnational ones. Firstly, because the doctrine of hardship finds no place in the Indian law of contract. Eventualities such as COVID-19 are likely to be detrimental to the price of performance - either by causing a dramatic increase or a decrease. This omission, consequently, places Indian law in an adverse position when compared to other major civil law jurisdictions, and in particular France, Austria, Germany, Greece, and the Netherlands to name a few - countries which not merely recognise hardship but permit the parties to adapt the terms of the existing contract to accommodate to changed circumstances, such as the onset and impact of a pandemic. In a related vein, India's reluctance in recognising hardship has also resulted in its judiciary disregarding any force majeure clause

\footnotetext{
198 Peacock, supra note 112, at 117, referring to the rules of the English law on the termination of a contract.

199 See Sec. 39 of the ICA; and text accompanying notes 150-160.
} 
which attempts to exonerate the parties from performing their contract when it has become more onerous but not impossible to perform. In other words, the party affected by hardship must either perform the contract "in its entirety" ${ }^{\prime 200}$ or face the consequences of breach under Indian law. Although Indian law requires a major overhaul through statutory reform, it is suggested that the Supreme Court exercise its power under Article 141 of the Constitution of India to reconsider the application of the doctrine of hardship in the country and also interpret force majeure clauses in a different light.

The fragmented notion of breach under Indian law also renders Indian law unsuitable to resolve transnational contracts - especially those concerning complex disputes that arise due to non-performance as the result of the COVID-19 outbreak. The parties must peruse more than a few provisions and maneuver their way through a jungle of case law to familiarise themselves with the consequences of breach. In such circumstances, the parties to an international contract will tend to prefer to adjudicate their disputes according to the laws not of India but of other countries.

\section{References}

Commentary on the UN Convention on the International Sale of Goods (CISG) (P. Schlechtriem \& I. Schwenzer (eds.), $4^{\text {th }}$ ed., Oxford: Oxford University Press, 2016). https:// doi.org/10.1093/law/9780198723264.001.0001

Khanderia S. Commercial Impracticability Under the Indian Law of Contract:Assessing the Role of the UNIDROIT Principles, 7(2) UCL Journal of Law and Jurisprudence 52 (2019).

Mulla D.F. Mulla on the Sale of Goods Act and the Indian Partnership Act $\left(10^{\text {th }}\right.$ ed., Delhi: Lexis Nexis, 2012).

Treitel G. Frustration and Force Majeure ( $3^{\text {rd }}$ ed., London: Sweet and Maxwell, 2014).

Vogenauer S. Introduction in Commentary on the UNIDROIT Principles of International Commercial Contracts (PICC) 7 (S. Vogenauer (ed.), $2^{\text {nd }}$ ed., Oxford: Oxford University Press, 2015).

\section{Information about the author}

Saloni Khanderia (Sonipat, India) - Associate Professor, Jindal Global Law School (OP Jindal Global University) (B1 805 Tulip Apartments, Sonipat-Narela Road, Sonipat, Haryana, 131001, India; e-mail: skhanderia@jgu.edu.in).

200 See Sec. 39 of the ICA; and text accompanying notes 150-160. 